\title{
SOIL LOSSES FROM TYPIC CAMBISOLS AND RED LATOSOL AS RELATED TO THREE EROSIVE RAINFALL PATTERNS ${ }^{(1)}$
}

\author{
Regimeire Freitas Aquino(2), Marx Leandro Naves Silva ${ }^{(3)}$, Diego Antonio França de \\ Freitas $^{(4)}$, Nilton Curi ${ }^{(3)}$ \& Junior Cesar Avanzi ${ }^{(5)}$
}

\begin{abstract}
SUMMARY
Rainfall erosivity is one of the main factors related to water erosion in the tropics. This work focused on relating soil loss from a typic dystrophic Tb Haplic Cambisol (CXbd) and a typic dystrophic Red Latosol (LVdf) to different patterns of natural erosive rainfall. The experimental plots of approximately $26 \mathrm{~m}^{2}(3 \times 8.67 \mathrm{~m})$ consisted of a CXbd area with a $0.15 \mathrm{~m} \mathrm{~m}^{-1}$ slope and a LVdf area with $0.12 \mathrm{~m} \mathrm{~m}^{-1}$ slope, both delimited by galvanized plates. Drainpipes were installed at the lower part of these plots to collect runoff, interconnected with a Geib or multislot divisor. To calculate erosivity $\left(\mathbf{E I}_{30}\right)$, rainfall data, recorded continuously at a weather station in Lavras, were used. The data of erosive rainfall events were measured $(10 \mathrm{~mm}$ precipitation intervals, accuracy $0.2 \mathrm{~mm}, 24 \mathrm{~h}$ period, $20 \mathrm{~min}$ intervals), characterized as rainfall events with more than $10 \mathrm{~mm}$ precipitation, maximum intensity > $24 \mathrm{~mm} \mathrm{~h}^{-1}$ within $15 \mathrm{~min}$, or kinetic energy $>3.6 \mathrm{MJ}$, which were used in this study to calculate the rainfall erosivity parameter, were classified according to the moment of peak precipitation intensity in advanced, intermediate and delayed patterns. Among the 139 erosive rainfall events with CXbd soil loss, $60 \%$ were attributed to the advanced pattern, with a loss of $415.9 \mathrm{Mg} \mathrm{ha}^{-1}$, and total losses of $776.0 \mathrm{Mg} \mathrm{ha}^{-1}$. As for the LVdf, of the 93 erosive rainfall events with soil loss, $58 \%$ were listed in the advanced pattern, with $37.8 \mathrm{Mg} \mathrm{ha}^{-1}$ soil loss and $50.9 \mathrm{Mg} \mathrm{ha}^{-1}$ of total soil loss. The greatest soil losses were observed in the advanced rain pattern, especially for the CXbd. From the Cambisol, the soil loss per rainfall event was greatest for the advanced pattern, being influenced by the low soil permeability.
\end{abstract}

Index terms: rainfall erosivity, water erosion, kinetic energy, soil erodibility.

(1) Part of the Master's Dissertation of the first author. Received for publication on March 12, 2012 and approved on November 9, 2012.

(2) Professor, Federal Institute of Education, Science and Technology. Rua Patronato, s/n, Lindo Vale. CEP 36307-384 São João Del Rei (MG), Brazil. E-mail: regimeire.aquino@ifsudestemg.edu.br

(3) Professor, Department of Soil Science, Federal University of Lavras (UFLA). CEP 37200-000 Lavras (MG), Brazil. Bolsista do CNPq. E-mail: marx@dcs.ufla.br; niltcuri@dcs.ufla.br

(4) Doctoral Student at the Federal University of Lavras. CEP 37200-000 Lavras (MG), Brazil. Exchange student at Purdue University with a scholarship from CAPES. Proc: BEX 2935/12-0. E-mail: diego_ufla@yahoo.com.br

(5) Researcher, Brazilian Agricultural Research Corporation (Embrapa). Quadra 103 Sul, Avenida JK, lote 17, Térreo. CEP 77015-012 Palmas (TO) Brazil. E-mail: junior.avanzi@embrapa.br 


\title{
RESUMO: PERDAS DE SOLO EM CAMBISSOLO E LATOSSOLO VERMELHO, EM RELAÇÃO A TRÊS PADRÕES DE CHUVAS EROSIVAS
}

\begin{abstract}
A erosividade da chuva é um dos principais fatores relacionados à erosão hídrica para as condições tropicais. Este trabalho teve como objetivo relacionar as perdas de solo em Cambissolo Háplico Tb distrófico típico (CXbd) e Latossolo Vermelho distrófico típico ( $L V d f)$, a diferentes padrões de chuvas erosivas naturais. A unidade experimental foi constituída de uma parcela com declive de 0,15 $\mathrm{m} \mathrm{m}^{-1}$, no CXbd, e 0,12 $\mathrm{m} \mathrm{m}^{-1}$, no LVdf, com aproximadamente $26 \mathrm{~m}^{2}(3 x$ $8,67 \mathrm{~m}$ ), sendo ambas delimitadas por chapas galvanizadas. Na parte inferior das parcelas, foram instaladas calhas coletoras para conduzirem a enxurrada para dois tanques, interligadas por um divisor tipo Geib. Para o cálculo da erosividade, utilizando o $\mathrm{EI}_{30}$, foram usados registros contínuos de dados pluviométricos, obtidos da Estação Climatológica de Lavras. A amplitude de registro desses dados foi de $10 \mathrm{~mm}$ de precipitação com acurácia de 0,2 $\mathrm{mm}$, tempo de registro de 24 h e unidade de medida de $20 \mathrm{~min}$. As chuvas erosivas, com precipitação maior que $10 \mathrm{~mm}$, intensidade máxima maior que $24 \mathrm{~mm} \mathrm{~h}^{-1}$, em $15 \mathrm{~min}$, ou energia cinética maior que 3,6 MJ, foram separadas em razão do ponto de ocorrência do pico de maior intensidade de precipitação em padrões avançado, intermediário e atrasado. Dentre as 139 chuvas erosivas para o CXbd, $60 \%$ concentraram-se no padrão avançado, com perdas de solo de 415,9 $\mathrm{Mg} \mathrm{ha}^{-1}$ e perdas totais de 776,0 Mg ha-1. Já para o LVdf, das 93 chuvas correspondentes, $58 \%$ caracterizaram-se no padrão avançado, representando $37,8 \mathrm{Mg} \mathrm{ha}^{-1}$ de perda de solo e 50,9 $\mathrm{Mg} \mathrm{ha}^{-1}$ de perdas de solo totais. As maiores perdas de solos foram observadas para o padrão de chuva avançado, notadamente para o CXbd. A umidade do solo antecedente à chuva e ao pico de maiores perdas de solos foi evidenciada para o padrão de chuva avançado, especialmente para o CXbd. No Cambissolo, as maiores perdas de solo por evento de chuva ocorreram no padrão avançado, sendo influenciado pela permeabilidade do solo.
\end{abstract}

Termos de indexação: erosividade da chuva, erosão hídrica, energia cinética, erodibilidade do solo.

\section{INTRODUCTION}

Soil erosion by water is one of the main environmental problems in Brazil, since the soil, water, nutrients and organic carbon carried off contribute to the impoverishment of the soil and the population that depends on it for basic needs. Soil erosion by water causes enormous damage to life on the planet, by polluting water and reducing the productivity, fertility and sustainability of agricultural systems (Arriaga \& Lowery, 2003), and by increasing environmental degradation, with huge implications for economic and social issues (Oliveira et al., 2010).

Of the main factors that influence soil erosion, rainfall erosivity is one of the hardest to predict and control (Martins et al., 2003). Erosivity is basically defined as the potential of rainfall to cause erosion, through detachment and transport of soil particles, depending on basic physical characteristics such as size, shape and fall speed of the raindrops (Oliveira et al., 2009).

The standard erosivity index defined by the Universal Soil Loss Equation (USLE) corresponds to the product of the rainfall kinetic energy by its maximum intensity in $30 \mathrm{~min}$, known as $\mathrm{EI}_{30}$ (Wischmeier \& Smith, 1958). This index is considered the most suitable for intertropical conditions (Bertoni \& Lombardi Neto, 1993), to calculate the local rainfall factor and, consequently, to fulfill the universality criterion of the soil loss equation. However, Kinnell (1981) declared that, for the same rainfall intensity, the erosive capacity varies according to the rainfall type (convective, frontal and orographic) and localization, especially altitude.

The factors that control the water infiltration in the soil, namely surface sealing, antecedent moisture, micro- and macro-relief, surface roughness and vegetation, also determine the volume of the runoff and the subsequent soil and water loss (Huggins \& Burney, 1982; Santos et al., 2009). Rainfall events with similar kinetic energy seldom occur under identical soil conditions, resulting in differentiated soil losses.

The potential of rainfall to cause water erosion may be better estimated from the correlation between rainfall erosivity parameters, flash flood and soil losses (Wischmeier \& Smith, 1978; Carvalho et al., 1993). Wischmeier \& Smith (1958) established the $\mathrm{EI}_{30}$ rainfall erosivity factor and studied the relationship between kinetic energy and soil loss, with a high correlation coefficient ( $\mathrm{r}=0.98)$.

It is generally verified that a larger amount of annual rainfall does not necessarily produce a higher $\mathrm{EI}_{30}$, because this rate is associated with higher rainfall concentration, as a result of climate characteristics, as well as from the dynamics and influence of factors associated with the atmospheric 
circulation (Mello et al., 2007). Furthermore, Silva (2004) concluded that the annual erosivity is closely related to the total precipitation, with a coefficient of determination of $97 \%$ of the parameters in erovisity maps of Brazil. Silva et al. (2009) found high correlations (94 and $98 \%$, respectively) between rainfall erosivity $\left(\mathrm{EI}_{30}\right)$ and soil loss from a typic Cambisol and a typic Latosol under natural rainfall, in five years of evaluation. In the East Central region of Minas Gerais, Silva et al. (2010) studied the spatialization of rainfall erosivity and found a correlation of $86 \%$ between $\mathrm{EI}_{30}$ rainfall erosivity and the monthly average precipitation, at nine locations.

Studying the effects of slope shape and rainfall energy and intensity on soil and water loss, Meyer \& Harmon (1992) concluded that, of the studied variables, rainfall intensity has the greatest influence on erosion, as also maintained by Mello et al. (2003). Therefore, Oliveira et al. (2010) reinforced the need to evaluate the response of soil classes to different kinds of rainfall, both in terms of precipitation volume and of duration and characteristics of the events.

Hence, due to the importance of the erosivity factor in the erosive process, especially in regions with concentrated erosive rainfall, this work focused on relating soil loss of typic dystrophic Tb Haplic Cambisol (CXbd) and typic dystrophic Red Latosol (LVdf) with different patterns of natural erosive rainfall.

\section{MATERIAL AND METHODS}

The study was carried out in an experimental area of the Department of Soil Science at the Federal University of Lavras (UFLA) $\left(21^{\circ} 14^{\prime} \mathrm{S}, 45^{\circ} 0^{\prime} \mathrm{W}\right.$; 919 $\mathrm{m}$ asl), located in the southern region of the State of Minas Gerais. The soils were classified according to Brazilian System of Soil Classification (Embrapa, 2006) as typic dystrophic Tb Haplic Cambisol, clayey texture (CXbd - Inceptsol) and typic dystrophic Red Latosol, very clayey texture (LVdf- Oxisol). The erosion plots on the different soils lie approximately $500 \mathrm{~m}$ apart. Soil physical and chemical properties are presented in table 1.

The land use before setting up the erosion plots was native pasture, for both soils. To install the experiment, the soil was plowed once with a disc plow and harrowed twice with a leveling harrow, in both slope directions. The whole soil surface was left bare. The experiment was monitored from January 1998 to December 2002, with one erosion plot per soil class, and the years of study were considered as replications. Spontaneous vegetation was hand-weeded. Whenever necessary, surface sealing was prevented by light chiseling.
The experimental erosion plots consisted of a CXbd area with $0.15 \mathrm{~m} \mathrm{~m}^{-1}$ slope and a LVdf area with 0.12 $\mathrm{m} \mathrm{m}^{-1}\left(3 \times 8.67 \mathrm{~m}\right.$ or approximately $26 \mathrm{~m}^{2}$ each), both delimited by galvanized sheets driven $20 \mathrm{~cm}$ deep into the ground with a height of $20 \mathrm{~cm}$ above the soil surface. Drainpipes were installed along the lower part of the plots to collect the runoff in two $225 \mathrm{~L}$ tanks, interconnected by a Geib divisor with nine windows, where the accumulated water in the second tank corresponds to 1/9 of the total runoff (Silva, 2003; Silva et al., 2005; Castro et al., 2011). Samples were collected as proposed by Cogo et al., (2003), to quantify soil loss after each erosive rainfall event.

To calculate erosivity $\left(\mathrm{EI}_{30}\right)$, rainfall data were used, recorded continuously at a weather station in Lavras, which belongs to the fifth Meteorological District, on the campus of the Federal University of Lavras (UFLA). The station is located $40 \mathrm{~m}$ away from the LVdf plots and $500 \mathrm{~m}$ from the CXbd plots. The data of rainfall events were measured $(10 \mathrm{~mm}$ precipitation intervals, accuracy $0.2 \mathrm{~mm}, 24 \mathrm{~h}$ period, $\geq 20$ min intervals). Only events of over $10 \mathrm{~mm}$ rainfall, with maximum intensity $>24 \mathrm{~mm} \mathrm{~h}^{-1}$ within $15 \mathrm{~min}$, or kinetic energy > 3.6 $\mathrm{MJ}$, were used in this study to calculate the rainfall erosivity. Individual rainfall events were distinguished by a period of more than $6 \mathrm{~h}$ and less than $1 \mathrm{~mm}$ precipitation (De Maria, 1994). After being manually listed in charts of uniform intensity, the total rainfall kinetic energy of each event was determined, using a specific program developed by Cataneo et al. (1982), which calculates the kinetic energy by the equation of Wischmeier \& Smith (1958):

$$
E=0.199+0.0873 \log I
$$

where $E$ is kinetic energy (MJ ha-1 $\mathrm{mm}^{-1}$ ), and $I$ is rainfall intensity $\left(\mathrm{mm} \mathrm{h}^{-1}\right)$.

The $\mathrm{EI}_{30}$ parameter $\left(\mathrm{MJ} \mathrm{mm} \mathrm{ha}{ }^{-1} \mathrm{~h}^{-1}\right)$ for a specific event was calculated as the product of total kinetic energy $(\mathrm{E})$ by the maximum 30 min intensity $\left(\mathrm{I}_{30}\right)$, according to Wischmeier \& Smith (1958).

Erosive rainfall events were separated in different patterns, according to the classification proposed by Horner \& Jens (1941) and modified by Mehl et al. (2001), by which rainfall events are classified in advanced, intermediate and delayed patterns, based on the moment of peak precipitation intensity. The rainfall pattern was considered advanced when the intensity peaked in the first $30 \%$ of the total rainfall duration; intermediate, when the highest intensity occurred within 30 and $60 \%$ of the total rainfall duration; and delayed, when the intensity peaked during the period after $60 \%$ of the total duration; the pattern was considered constant, when the intensity was constantly maintained throughout the entire event. After all rainfall patterns were determined, the soil losses measured after each rainfall event were separated according to each pattern. 


\section{RESULTS AND DISCUSSION}

Of the 139 erosive rainfall events with soil loss for $\mathrm{CXbd}, 60 \%$ were concentrated in the advanced pattern, with a total loss of $415.9 \mathrm{Mg} \mathrm{ha}^{-1}, 25 \%$ were classified as intermediate, with $216.9 \mathrm{Mg} \mathrm{ha}^{-1}$, and $15 \%$ in the delayed rainfall pattern, with a soil loss of $143.2 \mathrm{Mg} \mathrm{ha}^{-1}$ (Table 2). As for the LVdf, of the 93 erosive rainfall events with soil loss, $58 \%$ were listed in the advanced pattern, with $37.8 \mathrm{Mg} \mathrm{ha}^{-1}$ soil loss; $26 \%$ in the intermediate pattern, with $7.5 \mathrm{Mg}^{-1}$ soil loss; and $16 \%$ in the delayed pattern, with a loss of $5.6 \mathrm{Mg} \mathrm{ha}^{-1}$ (Table 2).
These results showed that the rainfall of Lavras region is characterized by advanced rainfall patterns. In this rainfall pattern, significant amounts of soil were lost from both the Cambisol and Latosol. However, delayed rainfalls pattern were responsible for the largest amount of soil eroded per erosive rainfall event from the CXbd. This shows that for this soil class, soil losses are intensified when the soil becomes saturated. For LVdf, this behavior was not observed for delayed rainfalls, due to the higher rate of soil permeability (Table 1).

The peak intensities were highest for the advanced rainfall pattern, where, interestingly, soil losses

Table 1. Chemical, physical and morphological properties of a typic dystrophic Tb Haplic Cambisol (CXbd) and a typic dystrofic Red Latosol (LVdf)

\begin{tabular}{|c|c|c|c|c|}
\hline \multirow{2}{*}{ Property $^{(1)}$} & \multicolumn{2}{|c|}{ CXbd } & \multicolumn{2}{|c|}{ LVdf } \\
\hline & A horizon & Bi horizon & A horizon & Bw horizon \\
\hline Depth (cm) & $0-14$ & $14-26$ & $0-56$ & $56-310$ \\
\hline $\mathrm{K}\left(\mathrm{g} \mathrm{kg}^{-1}\right)$ & 330 & 320 & 160 & 230 \\
\hline $\mathrm{Gb}\left(\mathrm{g} \mathrm{kg}^{-1}\right)$ & 190 & 180 & 310 & 400 \\
\hline $\mathrm{SiO}_{2}\left(\mathrm{~g} \mathrm{~kg}^{-1}\right)$ & 223 & 233 & 126 & 137 \\
\hline $\mathrm{Al}_{2} \mathrm{O}_{3}\left(\mathrm{~g} \mathrm{~kg}^{-1}\right)$ & 239 & 259 & 274 & 304 \\
\hline $\mathrm{Fe}_{2} \mathrm{O}_{3}\left(\mathrm{~g} \mathrm{~kg}^{-1}\right)$ & 33 & 43 & 292 & 296 \\
\hline TOC $\left(\mathrm{g} \mathrm{kg}^{-1}\right)$ & 22 & 11 & 60 & 9 \\
\hline Sand $\left(\mathrm{g} \mathrm{kg}^{-1}\right)$ & 478 & 430 & 259 & 110 \\
\hline Silt $\left(\mathrm{g} \mathrm{kg}^{-1}\right)$ & 158 & 170 & 124 & 60 \\
\hline Clay $\left(\mathrm{g} \mathrm{kg}^{-1}\right)$ & 364 & 400 & 617 & 830 \\
\hline FI $(\%)$ & 46 & 49 & 66 & 58 \\
\hline$\rho_{\text {bulk }}\left(\mathrm{Mg} \mathrm{m}^{-3}\right)$ & 1.40 & 1.38 & 1.20 & 0.95 \\
\hline$\rho_{\text {particle }}\left(\mathrm{Mg} \mathrm{m}^{-3}\right)$ & 2.47 & 2.54 & 2.69 & 2.78 \\
\hline $\mathrm{TP}\left(\mathrm{m}^{3} \mathrm{~m}^{-3}\right)$ & 0.46 & 0.46 & 0.51 & 0.66 \\
\hline Micro $\left(\mathrm{m}^{3} \mathrm{~m}^{-3}\right)$ & 0.40 & 0.36 & 0.41 & 0.38 \\
\hline $\operatorname{Macro}\left(\mathrm{m}^{3} \mathrm{~m}^{-3}\right)$ & 0.06 & 0.10 & 0.10 & 0.28 \\
\hline PERM $\left(\mathrm{mm} \mathrm{h}^{-1}\right)$ & 14 & 9 & 74 & 201 \\
\hline
\end{tabular}

${ }^{(1)}$ K: Kaolinite; Gb: gibbsite; TOC: total organic carbon; FI: flocculation index; $\rho_{\text {bulk }}$ : bulk density; $\rho_{\text {particle }}$ : particle density; TP: total porosity; Micro: micropore; Macro: macropore; PERM: soil permeability. Bi: horizon B incipient; Bw: horizon B weathering. Source: Silva et al. (2009).

Table 2. Amount of erosive rainfall, soil loss and soil loss percentage in three different patterns of erosive rainfall events in the region of Lavras, MG

\begin{tabular}{|c|c|c|c|c|c|c|c|c|}
\hline \multirow{3}{*}{ Parameter } & \multicolumn{8}{|c|}{ Soil } \\
\hline & \multicolumn{4}{|c|}{$\mathbf{C X b d}^{(1)}$} & \multicolumn{4}{|c|}{ LVdf $f^{(2)}$} \\
\hline & $\mathbf{A} \mathbf{V}^{(\mathbf{3})}$ & $\mathbf{I N}^{(4)}$ & $\mathbf{D} \mathbf{E}^{(\mathbf{5})}$ & Total & $\mathbf{A V}$ & IN & DE & Total \\
\hline Erosive rainfall $\left(\mathrm{n}^{0}\right)$ & 83 & 35 & 21 & 139 & 54 & 24 & 15 & 93 \\
\hline Soil loss $\left(\mathrm{Mg} \mathrm{ha}^{-1}\right)$ & 415.9 & 216.9 & 143.2 & 776.0 & 37.8 & 7.5 & 5.6 & 50.9 \\
\hline Soil loss $(\%)^{(6)}$ & 54 & 28 & 18 & 100 & 74 & 15 & 11 & 100 \\
\hline Soil loss per rainfall event $\left(\mathrm{Mg} \mathrm{ha}^{-1}\right)^{(7)}$ & 5.0 & 6.2 & 6.8 & 5.6 & 0.7 & 0.3 & 0.4 & 0.5 \\
\hline
\end{tabular}

${ }^{(1)} \mathrm{CXbd}$ : typic Dystrophic Tb Haplic Cambisol. ${ }^{(2)}$ LVdf: typic Dystrophic Red Latosol. ${ }^{(3)} \mathrm{AV}$ : Advanced erosive rainfall pattern; ${ }^{(4)} \mathrm{IN}$ : Intermediate erosive rainfall pattern; ${ }^{(5)} \mathrm{DE}$ : Delayed erosive rainfall pattern; ${ }^{(6)}$ Soil loss $(\%)$ represents soil loss for each rainfall pattern divided by total soil loss, multiplied by $100 ;{ }^{(7)}$ Soil loss per rainfall event $\left(\mathrm{Mg} \mathrm{ha}^{-1}\right)$ represents soil loss in each rainfall pattern divided by the number of erosive rainfall events. 
differed between CXbd and LVdf(39.1 and $1.8 \mathrm{Mg} \mathrm{ha}^{-1}$ soil loss from CXbd and LVdf, respectively), for the same rainfall event with only $4 \mathrm{~h}$ duration and an erosive potential of 1,663 MJ mm ha-1 $\mathrm{h}^{-1}\left(\mathrm{EI}_{30}\right)$. The peak intensity which characterized this rainfall event as advanced was $134 \mathrm{~mm} \mathrm{~h}^{-1}$, initiating an hour and a half after the beginning of the event. The accumulated precipitation at the peak intensity was $67 \mathrm{~mm}$, equivalent to $77.7 \%$ of the total precipitation (Table 3 ).

A rainfall erosivity of $110 \mathrm{MJ} \mathrm{mm} \mathrm{ha}^{-1} \mathrm{~h}^{-1}$ and peak intensity characterizing the rainfall pattern as advanced (144 $\mathrm{mm} \mathrm{h}^{-1}$ ), led to a CXbd soil loss 2.84 times higher in than LVdf loss (Table 3).

These examples demonstrate the need to obtain the best correlation between soil losses and the variables that constitute the rainfall erosivity index $\left(\mathrm{EI}_{30}\right)$, which is hampered by the limited knowledge on rainfall physical characteristics, since soil losses are related not only to their erosive potential, but also to the location of the highest peak intensity, the moisture antecedent to the rainfall and also the moisture antecedent to the peak intensity (Eltz et al., 2001; Loyola \& Prevedello, 2003; Silva et al., 2009).

Another example in which the precipitation antecedent to the peak intensity is high, during short-term rainfall, can be observed in the $156 \mathrm{MJ}$ $\mathrm{mm} \mathrm{ha}^{-1} \mathrm{~h}^{-1}$ erosive rainfall event, with a duration of $2 \mathrm{~h}$ and $20 \mathrm{~min}$, where CXbd soil loss was $59.7 \mathrm{Mg} \mathrm{ha}^{-1}$. The maximum peak intensity was $120 \mathrm{~mm} \mathrm{~h}^{-1}$, reached 10 min after the beginning of the rainfall with $74 \%$ of the total accumulated precipitation. For the LVdf, soil loss was not registered in this event, which can be related to the beginning of the rainy season, where soil still has a higher infiltration capacity, leading to lower runoff rates.
The effect of moisture antecedent to the rainfall can be observed during the intermediate pattern event, with $43.4 \mathrm{Mg} \mathrm{ha}^{-1}$ for CXbd and $0.1 \mathrm{Mg} \mathrm{ha}^{-1}$ for LVdf, knowing that a rainfall occurred $24 \mathrm{~h}$ before, with 33 $\mathrm{mm}$ precipitation. A delayed pattern rainfall with a maximum intensity of $65 \mathrm{~mm} \mathrm{~h}^{-1}$ caused soil losses of 49.1 $\mathrm{Mg} \mathrm{ha}^{-1} \mathrm{CXbd}$ and $1.8 \mathrm{Mg} \mathrm{ha}^{-1} \mathrm{LVdf}$. These losses can be attributed to the rainfall physical factors, such as: average intensity of the event $\left(41 \mathrm{~mm} \mathrm{~h}^{-1}\right)$, short duration, and erosivity of $1,084 \mathrm{MJ} \mathrm{mm} \mathrm{ha} \mathrm{m}^{-1} \mathrm{~h}^{-1}$. The antecedent rainfall began $24 \mathrm{~h}$ before with precipitation of $86 \mathrm{~mm}$. Rain with similar erosivity can cause different soil losses, depending on the moisture antecedent to the rainfall and the intensity variation during the rainfall, due to high intensity peaks (Table 4), since higher soil moisture reduces the infiltration capacity while the soil detachment due to raindrop impact is favored, causing surface sealing and runoff (Flanagan et al., 1988). Silva et al. (2009) stated that non-erosive rainfalls, especially on more shallow soils, can cause quick saturation, leading to more surface detachment and removal of soil particles than from deeper soils.

In table 5, two rainfall events can be noted with the same erosivity level and similar soil losses, but rather different physical characteristics. During the first event, rainfall intensity was high from the very first minutes, when the soil was detached by raindrop impact. During the second event, on the other hand, rainfall intensity was significantly lower, although continuous until the maximum intensity peak was reached, and the total precipitation amount doubled, compared to the first event. This demonstrated how the effect of the soil moisture antecedent to the rainfall intensity peak is essential for the sediment generation and transport process and that it needs to be considered

Table 3. Soil loss and rainfall characteristics for different rainfall patterns

\begin{tabular}{|c|c|c|c|c|c|c|c|}
\hline \multirow{3}{*}{ Soil Loss } & \multicolumn{7}{|c|}{ Rainfall characteristic } \\
\hline & \multicolumn{2}{|c|}{ Time } & \multicolumn{2}{|c|}{ Precipitation } & \multicolumn{2}{|c|}{ Intensity } & \multirow{2}{*}{ Erosivity } \\
\hline & Maximum & Total & Maximum & Total & Maximum & Average & \\
\hline $\mathrm{Mg} \mathrm{ha}^{-1}$ & \multirow{2}{*}{\multicolumn{2}{|c|}{$\longrightarrow$ hour }} & $-\mathrm{n}$ & 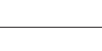 & \multicolumn{2}{|c|}{$\longrightarrow \mathrm{mm} \mathrm{h}^{-1}$} & MJ mm ha ${ }^{-1} h^{-1}$ \\
\hline \multicolumn{6}{|c|}{ Advanced pattern } & & \\
\hline $\begin{array}{r}39.1^{(1)} \\
1.8^{(2)}\end{array}$ & 1.62 & 4.03 & 67.0 & 85.9 & 134 & 30 & 1,663 \\
\hline $\begin{array}{r}12.2^{(1)} \\
4.3^{(2)}\end{array}$ & 0.67 & 4.17 & 12.4 & 17.4 & 144 & 18 & 110 \\
\hline $\begin{array}{r}59.7^{(1)} \\
0.0^{(2)}\end{array}$ & 0.17 & 2.33 & 14.2 & 19.2 & 120 & 27 & 156 \\
\hline \multicolumn{8}{|c|}{ Intermediate pattern } \\
\hline $\begin{array}{r}43.4^{(1)} \\
0.1^{(2)}\end{array}$ & 7.67 & 16.00 & 18.9 & 41.2 & 110 & 12 & 441 \\
\hline \multicolumn{8}{|c|}{ Delayed pattern } \\
\hline $\begin{array}{r}49.1^{(1)} \\
1.8^{(2)}\end{array}$ & 2.50 & 2.67 & 67.2 & 78.1 & 65 & 41 & 1,084 \\
\hline
\end{tabular}

${ }^{(1)}$ Data of a typic dystrophic Tb Haplic Cambisol (CXbd); ${ }^{(2)}$ Data of a typic dystrophic Red Latosol (LVdf). 
Table 4. Soil loss related to rainfall events with similar characteristics in the region of Lavras, MG

\begin{tabular}{|c|c|c|c|c|c|c|c|}
\hline \multirow{3}{*}{ Soil Loss } & \multicolumn{7}{|c|}{ Rainfall characteristic } \\
\hline & \multicolumn{2}{|c|}{ Time } & \multicolumn{2}{|c|}{ Precipitation } & \multicolumn{2}{|c|}{ Intensity } & \multirow{2}{*}{ Erosivity } \\
\hline & Maximum & Total & Maximum & Total & Maximum & Average & \\
\hline $\mathrm{Mg} \mathrm{ha}^{-1}$ & $\longrightarrow \mathrm{r}$ & $\longrightarrow$ & $\longrightarrow \mathrm{m}$ & - & $-\mathrm{m}$ & $h^{-1}$ & MJ mm ha- $\mathrm{h}^{-1}$ \\
\hline $\begin{array}{l}2.04^{(1)} \\
0.02^{(2)}\end{array}$ & 0.12 & 3.50 & 0.7 & 4.4 & 15 & 5 & 5 \\
\hline $\begin{array}{l}0.23^{(1)} \\
0.05^{(2)}\end{array}$ & 2.08 & 21.08 & 17.0 & 26.0 & 36 & 6 & 5 \\
\hline $\begin{array}{l}0.01^{(1)} \\
0.02^{(2)}\end{array}$ & 0.03 & 2.42 & 2.0 & 3.6 & 60 & 12 & 5 \\
\hline $\begin{array}{l}0.01^{(1)} \\
0.00^{(2)}\end{array}$ & 5.17 & 8.00 & 4.6 & 7.0 & 10 & 2 & 5 \\
\hline $\begin{array}{l}0.08^{(1)} \\
0.03^{(2)}\end{array}$ & 1.67 & 1.72 & 2.0 & 4.8 & 34 & 11 & 5 \\
\hline $\begin{array}{l}0.02^{(1)} \\
0.15^{(2)}\end{array}$ & 0.97 & 17.5 & 5.6 & 25.6 & 18 & 10 & 40 \\
\hline $\begin{array}{l}1.39^{(1)} \\
0.00^{(2)}\end{array}$ & 0.58 & 5.08 & 4.0 & 16.0 & 22 & 6 & 40 \\
\hline $\begin{array}{l}2.03^{(1)} \\
0.00^{(2)}\end{array}$ & 0.42 & 3.25 & 6.6 & 11.2 & 24 & 7 & 40 \\
\hline $\begin{array}{l}3.53^{(1)} \\
0.08^{(2)}\end{array}$ & 0.83 & 8.33 & 14.8 & 21.8 & 43 & 5 & 154 \\
\hline $\begin{array}{r}59.68^{(1)} \\
0.00^{(2)}\end{array}$ & 0.17 & 2.33 & 14.2 & 19.2 & 120 & 27 & 154 \\
\hline
\end{tabular}

Table 5. Events with identical soil losses for the same rainfall characteristics in the region of Lavras, MG.

\begin{tabular}{|c|c|c|c|c|c|c|c|}
\hline \multirow{3}{*}{ Soil Loss } & \multicolumn{7}{|c|}{ Rainfall characteristic } \\
\hline & \multicolumn{2}{|c|}{ Time } & \multicolumn{2}{|c|}{ Precipitation } & \multicolumn{2}{|c|}{ Intensity } & \multirow{2}{*}{ Erosivity } \\
\hline & Maximum & Total & Maximum & Total & Maximum & Average & \\
\hline $\mathrm{Mg} \mathrm{ha}^{-1}$ & $\longrightarrow \mathrm{r}$ & 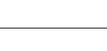 & $\longrightarrow \mathrm{n}$ & - & $-\mathrm{m}$ & $\mathrm{h}^{-1}$ & MJ mm ha ${ }^{-1} h^{-1}$ \\
\hline $\begin{array}{l}0.01^{(1)} \\
0.02^{(2)}\end{array}$ & 0.03 & 2.42 & 2.0 & 3.6 & 60 & 12 & 5 \\
\hline $\begin{array}{l}0.01^{(1)} \\
0.00^{(2)}\end{array}$ & 5.17 & 8.00 & 4.6 & 7.0 & 10 & 2.0 & 5 \\
\hline
\end{tabular}

${ }^{(1)}$ Data of the typic dystrophic Tb Haplic Cambisol (CXbd); ${ }^{(2)}$ Data of the typic dystrophic Red Latosol (LVdf).

in studies on the correlation between rainfall erosivity and soil losses. Therefore, Eltz et al. (2001) stated that rainfalls that lead to the same erosivity can provoke different soil losses, depending on the soil moisture antecedent to the rainfall and its intensity variation. In this case, it can be expected that natural rainfalls with high intensity peaks towards the end produce higher soil and water loss than rainfalls whose higher intensity peaks appear at the beginning or in the middle (Mendes et al., 2011); although this statement differs from the results presented in table 3.

\section{CONCLUSIONS}

1.There was a significant difference of soil loss from the two studied soil classes within a same period of time. The highest soil losses were observed for rainfalls with an advanced pattern, mainly from the Cambisol.

2. The soil moisture antecedent to the rainfall and to the highest rainfall intensity peak was critical in this water erosion study. 


\section{ACKNOWLEDGEMENTS}

The authors wish to thank the Research Foundation of the State of Minas Gerais (FAPEMIG); the Brazilian Coffee Research and Development Consortium (CBP\&D/café), for financial support of the project; and the National Institute of Meteorology of Minas Gerais (INMET/MG), for authorizing the use of pluviometric data from Lavras, MG.

\section{LITERATURE CITED}

ARRIAGA, F.J. \& LOWERY, B. Erosion and productivity. In: STEWART, B.A. \& HOWELL, T., eds. Encyclopedia of water science. New York, Marcel Dekker, 2003. p.222224.

BERTONI, J. \& LOMBARDI NETO, F. Conservação do solo. São Paulo, Ícone, 1993. 355p.

CARVALHO, M.P.; CATANEO, A. \& LOMBARDI NETO, F. Índice de erosividade da chuva e enxurrada correlacionados com as perdas de solo e determinação da erodibilidade de um Latossolo Roxo distrófico de Campinas-SP. R. Bras. Ci. Solo, 17:445-450, 1993.

CASTRO, N.A.E.; SILVA, M.L.N.; FREITAS, D.A.F.; CARVAHO, G.J.; MARQUES, R.M. \& GONTIJO, G.F. Plantas de cobertura no controle da erosão hídrica sob chuvas naturais. Biosci. J., 27:775-785, 2011.

CATANeO, A.; CASTRO FILHO, C.; ACQUAROLE, R.M. Programa para cálculo de erosividade da chuva. R. Bras. Ci. Solo, 6:236-239, 1982.

COGO, N.P.; LEVIEN, R. \& SCHWARZ, R.A. Perdas de solo e água por erosão hídrica influenciadas por métodos de preparo, classes de declive e níveis de fertilidade do solo. R. Bras. Ci. Solo, 27:743-753, 2003.

DE MARIA, I.C. Cálculo da erosividade da chuva. In: Manual de programas de processamento de dados de campo e de laboratório para fins de experimentação em conservação do solo. Campinas, IAC-SCS, 1994. Não Paginado.

ELTZ, F.L.F.; MEHL, H.U. \& REICHERT, J.M. Perdas de solo e água em entressulcos em um Argissolo VermelhoAmarelo submetido a quatro padrões de chuva. R. Bras. Ci. Solo, 25:85-493, 2001.

EMPRESA BRASILEIRA DE PESQUISA AGROPECUÁRIA - EMBRAPA. Sistema brasileiro de classificação de solos. 2.ed. Rio de Janeiro, Embrapa Solos, 2006. 306p.

FLANAGAN, D.C.; FOSTER, G.R. \& MOLDENHAUER, W.C. Storm pattern effect on infiltration, runoff, and erosion. Trans. Am. Soc. Agric. Eng., 31:414-420, 1988.

HORNER, W.W. \& JENS, S.W. Surface runoff determination from rainfall without using coefficients. Trans. Am. Soc. Agric. Eng., 107:1039-1117, 1941.
HUGGINS, L.F. \& BURNEY, J.R. Surface runoff, storage and routing. In: HAAN, C.T.; JONHSON, H.P. \& BRAKENSIEK, D.L., eds. Hydrologic modeling of small water-sheds. St. Joseph, ASAE, 1982. p.169-225.

KINNELL, P.I.A. Rainfall intensity-kinetic energy relationship for soil loss prediction. Soil Sci. Soc. Am. J., 45:153-155, 1981.

LOYOLA, J.M.T. \& PREVEDELLO. C.L. Modelos analíticos para predição do processo da redistribuição da água no solo. R. Bras. Ci. Solo, 27:783-787, 2003.

MARTINS, S.G.; SILVA, M.L.N.; CURI, N.; FERREIRA, M.M.; FONSECA, S. \& MARQUES, J.J.G.S.M. Perdas de solo e água por erosão hídrica em sistemas florestais na região de Aracruz (ES). R. Bras. Ci. Solo, 27:395-403, 2003.

MEHL, H.U.; ELTZ, F.L.F.; REICHERT, J.M. \& DIDONÉ, I.A. Caracterização de padrões de chuvas ocorrentes em Santa Maria (RS). R. Bras. Ci. Solo, 25:475-483, 2001.

MELLO, C.R.; LIMA, J.M.; SILVA, A.M. \& LOPES, D. Abstração inicial da precipitação em micro-bacias hidrográficas com escoamento efêmero. R. Bras. Eng. Agríc. Amb., 7:494$500,2003$.

MELLO, C.R.; SÁ, M.A.C.; CURI, N.; MELLO, J.M.; VIOLA, M.R. \& SILVA, A.M. Erosividade mensal e anual da chuva no Estado de Minas Gerais. Pesq. Agropec. Bras., 42:537-545, 2007.

MENDES, C.A.R.; MAHLER, C.F. \& ANDRADE, A.G. Erosão superficial em Argissolo Amarelo sob cultivo perene e com pousio florestal em área de relevo montanhoso. R. Bras. Ci. Solo, 35:1387-1396, 2011.

MEYER, L.D. \& HARMON, W.C. Interrill runoff and erosion: Effects of row-sideslope shape, rain energy, and rain intensity. Trans. Am. Soc. Agric. Eng., 35:1199-1203, 1992.

OLIVEIRA, F.P.; SILVA, M.L.N.; CURI, N.; SILVA, M.A. \& MELLO, C.R. Potencial erosivo da chuva no vale do rio doce, região centro leste do estado de Minas Gerais: Primeira aproximação. Ci. Agrotec., 33:1569-1577, 2009.

OLIVEIRA, J.R.; PINTO, M.F.; SOUZA, W.J.; GUERRA, J.G.M. \& CARVALHO, D.F. Erosão hídrica em um Argissolo Vermelho-Amarelo, sob diferentes padrões de chuva simulada. R. Bras. Eng. Agríc. Amb., 14:140-147, 2010.

SANTOS, T.E.M.; MONTENEGRO, A.A.A. \& PEDROSA, E.R Características hidráulicas e perdas de solo e água sob cultivo do feijoeiro no semi-árido. R. Bras. Eng. Agríc. Amb., 13:217-225, 2009.

SILVA, A.M. Erosividade, erodibilidade e perdas por erosão em Cambissolo e Latossolo sob chuva natural. Lavras, Universidade Federal de Lavras, 2003. 71p. (Dissertação de Mestrado)

SILVA, A.M. Rainfall erosivity map for Brazil. Catena, 57:251$259,2004$.

SILVA, A.M.; SILVA, M.L.N.; CURI, N.; LIMA, J.M.; AVANZI, J.C. \& FERREIRA, M.M. Perdas de solo, água, nutrientes e carbono orgânico em Cambissolo e Latossolo sob chuva natural. Pesq. Agropec. Bras., 40:1223-1230, 2005. 
SILVA, A.M.; SILVA, M.L.N.; CURI, N.; AVANZI, J.C. \& FERREIRA, M.M. Erosividade da chuva e erodibilidade de Cambissolo e Latossolo na região de Lavras, Sul de Minas Gerais. R. Bras. Ci. Solo, 33:1811-1820, 2009.

SILVA, M.A.; SILVA, M.L.N.; CURI, N.; SANTOS, G.R.; MARQUES, J.J.G.S.E.M.; MENEZES, M.D. \& LEITE, F.P. Avaliação e espacialização da erosividade da chuva no Vale do Rio Doce, região Centro-leste do Estado de Minas Gerais. R. Bras. Ci. Solo, 34:1029-1039, 2010.
WISCHMEIER, W.H. \& SMITH, D.D. Predicting energy erosion losses; A guide to conservation planning. Washington, USDA, 1978. 58p. (USDA. Agricultural Handbook, 537)

WISCHMEIER, W.H. \& SMITH, D.D. Rainfall energy and its relationship to soil loss. Trans. Am. Soc. Agric. Eng., 39:285-291, 1958. 